\title{
The Impact of Housing Densification on Shading Potential of Open Spaces: A Case Study
}

\author{
Omar S. Asfour ${ }^{1,2}$
}

check for

Citation: Asfour, O.S. The Impact of Housing Densification on Shading Potential of Open Spaces: A Case Study. Sustainability 2022, 14, 1294. https://doi.org/10.3390/su14031294

Academic Editor: Vesna Kosorić

Received: 16 December 2021

Accepted: 18 January 2022

Published: 24 January 2022

Publisher's Note: MDPI stays neutral with regard to jurisdictional claims in published maps and institutional affiliations.

Copyright: (C) 2022 by the author. Licensee MDPI, Basel, Switzerland. This article is an open access article distributed under the terms and conditions of the Creative Commons Attribution (CC BY) license (https:// creativecommons.org/licenses/by/ $4.0 /)$.
1 Architecture Department, King Fahd University of Petroleum \& Minerals, Dhahran 31261, Saudi Arabia; mar.asfour@kfupm.edu.sa or o.asfour@hotmail.com; Tel.: +966-13-8603594; Fax: +966-13-8603210

2 Interdisciplinary Research Center for Construction and Building Materials, King Fahd University of Petroleum \& Minerals, Dhahran 31261, Saudi Arabia

\begin{abstract}
This study discusses housing densification as a sustainable housing strategy. Furthermore, it investigates how housing densification can improve the shading performance of open spaces with respect to row-house typology. The analysis considers a real-time case study of linear courtyards enclosed by row houses. Urban analysis was followed by a numerical shading analysis to examine the impact of housing attachment method (aligned or stepped) on courtyard shading potential. Row houses were found to be an acceptable housing densification solution in Saudi Arabia, with wellintegrated open spaces. The stepped-attached housing pattern showed a higher potential for urban shading (by $\sim 55 \%$ with an east-west orientation of row houses) than that of the aligned-attached pattern. In addition, the stepped-attached housing pattern improved the visual quality and created a serial visual effect. This study recommends the promotion of compact housing patterns in Saudi Arabia to reduce the rapidly increasing domestic electrical-energy demand and improve urban shading. Housing densification is considered as an effective passive design and planning strategy for this purpose.
\end{abstract}

Keywords: courtyard; densification; housing; row houses; shading

\section{Introduction}

One main aspect of sustainable cities is to provide a healthy urban environment that helps improve the quality of life of their inhabitants. The way we plan and design our cities is believed to strongly affect our social well-being. Sustainable housing can be defined as "housing that creates sustainable communities in a resource-efficient manner" [1]. However, there is limited public awareness in this regard, and several sociocultural barriers to implementing sustainability in the housing sector [2]. This includes the exaggerated housing-unit area, which is $625 \mathrm{~m}^{2}$ in Saudi Arabia on average. This unnecessary space increases domestic energy consumption and $\mathrm{CO}_{2}$ emissions [3]. A large proportion (50\%) of domestic energy in Saudi Arabia is consumed by air conditioning, which is caused by lack of proper thermal insulation in $70 \%$ of the existing residential buildings. Therefore, thermal insulation has become an obligatory requirement for new building-design approval. Improving the thermal insulation levels of existing and new buildings is expected to reduce the electricity consumption of buildings by $\sim 30-40 \%$ [4].

However, there is a need to enhance the implementation of other passive design strategies on both the building-design and urban-design levels [5,6]. One important strategy in this regard is urban densification. Several studies have investigated the impact of housing densification on urban shading (see Section 2 for details). To advance the current research in this field, our study investigates the potential impact of row houses on enhancing urban shading under the urban and climatic conditions of Saudi Arabia. Although this housing typology is uncommon in Saudi Arabia compared with the single-family detached houses, it can be effectively used to satisfy the need for housing densification. Moreover, it may 
offer a socially acceptable housing type with common open spaces and separate entrances to each housing unit. The row typology is expected to support official efforts to reduce domestic energy consumption and improve the quality of the urban environment.

Using a real-time case study, this paper discusses a row-housing project in Saudi Arabia. The study begins with a literature review of housing densification and the urban role of open spaces, and then presents the research materials and methods. In the empirical part, the study carries out an urban analysis of the case study. The potential of urban densification to enhance shading in outdoor open spaces embedded in the housing environment is investigated using a numerical parametric simulation with several variables, such as building height, open-space orientation, and attachment method of housing blocks. The results of this study will provide recommendations that could become part of the future urban development policy of the Saudi city. The findings of this study should also be applicable to many other neighboring countries with similar climatic and sociocultural conditions.

\section{Literature Review}

\subsection{Housing Densification as a Sustainable Strategy}

As opposed to urban expansion, urban densification can accommodate rapid urban population growth [7]. Municipalities can adopt urban densification to maximize the benefits of the existing resources within urban areas. As such, urban densification is commonly considered as a sustainable strategy that considerably influences resource efficiency [8]. Urban densification can take many forms, including "soft" and "hard" ones. Soft densification includes progressive policies that encourage residents to optimize the use of their land plots without radically changing the existing urban form. For example, large plots can be divided into smaller subplots, or additional living quarters can be added to the existing units through a refurbishment process. Conversely, hard densification considerably alters the urban form, for example, by replacing detached houses with apartment buildings and their required services $[9,10]$.

Urban densification can be effectively implemented in new housing developments using high urban density that is consistent with local building regulations [11]. In existing housing developments, it can be achieved by filling vacant zones in the city. In all cases, densification policies should be handled with care, because they exert multiple socioeconomic and cultural impacts. The main aim of urban densification is to optimize the use of space, public services, and infrastructure to help save energy, reduce $\mathrm{CO}_{2}$ emissions, and mitigate the phenomenon of urban heat islands (UHIs) [12]. The main passive cooling advantage of urban densification is that it protects buildings from unwanted heat gains by reducing their external surface areas exposed to direct sun and unwanted thermal gains. This advantage can be achieved by attaching housing units horizontally, stacking them vertically, or combining both approaches. However, urban densification should not compromise the adequate provision of open spaces. In modern cities, there is a growing concern that limiting the use of public open space may cause deterioration in the health and well-being of residents in the housing environments [13,14].

\subsection{Housing Typologies in Saudi Arabia}

Housing demand in Saudi Arabia depends on several factors, including household income, housing-unit price, rate of population growth, and demand for housing finance solutions, such as loans [15]. The main challenge in this regard is the current and projected gap between housing supply and demand. As the requirements and cost of housing increase, middle- and low-income families face challenges in owning a housing unit [16]. Saudi Vision 2030 [17] aimed to increase citizens' ownership of housing units from 50\% in 2016 to $60 \%$ in 2020 , and its current goal is $70 \%$ for 2030 . To reach this goal, the government has developed several housing-investment-enabling policies that encourage the engagement of the private sector in housing supply. Furthermore, it has developed affordable housing programs, such as Sakani, which is a real estate initiative that facilitates 
people to own their first housing unit. It also offers many other solutions related to housing land, housing self-construction, and housing renovation initiative [18].

In this context, new urban planning solutions that improve housing affordability are also required in the Saudi housing sector. For instance, land-subdivision methods should be improved to encourage efficient land use and smart growth principles [19]. This solution would control horizontal urban sprawl and thereby reduce the cost of housing infrastructure [20]. Introducing economic housing typologies would also improve housing affordability. Several housing typologies could be recognized in Saudi Arabia. According to the General Authority of Statistics [21], the main housing typologies in Saudi Arabia are apartment houses $(44 \%)$, villas (29\%), single floors in villas (8\%), and traditional houses $(19 \%)$. Attached units, including semiattached (duplex) and attached units (row houses), are less common. As these typologies offer an acceptable, more affordable alternative for those who cannot afford the initial and running cost of villas but hope to own a private housing unit, their popularity is expected to increase in future [22].

\subsection{Open Spaces Embedded in Dense Residential Zones}

In general, urban built forms (including dense urban patterns) should be used to create open spaces that serve as social spaces at the same time. Open spaces in housing environments are among the most important image-making urban elements that help develop a sense of place in cities. Moreover, they are the main determinant of housing community structure or housing grouping patterns. Open spaces provide socializing and recreational opportunities that enhance the quality of life of residents. To ensure their efficiency, open spaces embedded in housing environments should be well-planned and designed to satisfy the residents' requirements and expectations. Among the suggested attributes of good public open spaces are sufficient area, accessibility, safety, visual interest, and inclusion of proper climatic protection measures, such as shading in hot climates [23,24]. This last attribute is essential in Saudi Arabia and other countries characterized by hot climatic conditions.

On a general level, urban structure is based on three main elements: space, built environment, and movement system. Buildings are human-made physical entities that can affect open space quality through the relationship they offer between open space and users. Residential buildings gain a special importance in this regard [25]. Open space refers to "any open piece of land that is undeveloped (has no buildings or other built structures) and is accessible to the public". This includes green areas, public plazas, playgrounds, and vacant lots [26]. They could be centralized or decentralized, private, public, or semi-public. They have four urban levels: pocket or local level, neighborhood level, city level, regional level, and national level. Local open spaces refer to the relatively small open areas that serve the recreation needs of the immediate residents. Neighborhood open spaces are larger and serve the neighborhood community within a reasonable walking distance [27]. Open spaces could also be effectively used to add vegetation and landscape features, and play an important role in improving people's quality of life [28]. This is a main target of the 2030 Sustainable Agenda, Sustainable Development Goal 11 "Sustainable Cities and Communities" [29]. This is also a main objective of the Saudi Vision 2030, Quality of Life program [30].

Modern city temperatures in Saudi Arabia and elsewhere have been increasing owing to several factors, including climate change and the lack of holistic approaches for passive urban-design strategies. In Saudi Arabia, the prevailing climate is the desert climate [31]. The UHI effect considerably correlates with urban configuration [32,33] but can be mitigated by urban shading. Therefore, urban shading is essential for improving microclimatic conditions. A UHI refers to a built-up area that becomes hotter than its adjacent rural areas, owing to urbanism and the replacement of green areas by buildings. The UHI effect substantially increases the energy demand of buildings, mainly by increasing the need for air conditioning in hot climates, which results in increased emissions of greenhouse gases [34]. Moreover, it increases outdoor thermal discomfort and soil dryness. The UHI effect is com- 
monly mitigated by increasing the green coverage area using native plants, installing cool roofs and paving, and improving urban shading with proper building massing $[32,35,36]$.

Although Saudi Arabia has several climatic zones, most of its provenances are dominated by the desert climate, which is characterized by hot climatic conditions in summer and very low annual rainfall [37]. Under such conditions, shading provision in the built environment, including open spaces, is an essential passive design strategy for improving outdoor thermal comfort, as well as mitigating solar heat gains and their related phenomena (such as the UHI effect). Furthermore, increasing the amount of urban shading is believed to considerably reduce energy consumption. Common examples are courtyard houses (on a single-building level) [38,39] and housing clusters (on an urban level) [40,41]. Among the solutions for urban shading are compact urban patterns that use building masses as shading elements. This should be done without compromising the need for avoiding urban crowding, which is usually controlled by urban regulations that specify maximum urban density for any given urban context.

Several studies have investigated the impact of housing densification on urban shading [42-46]. For example, Masoud et al. [47] examined the effect of urban forms on the shading of pedestrians. They adopted the sky-view factor (SVF) as an indicator of solar access, considering the hot climate conditions of Jeddah, Saudi Arabia. They examined the benefit of urban densification in the old part of Jeddah city, a representative compact neighborhood in an urban setting. They found that the SVF effectively indicates solar access in urban morphology. Moro et al. [48] conducted a shading analysis of some urban public squares surrounded by building masses. Using satellite imagery and a geographic information system, they calculated the percentages of shaded areas in the examined open spaces. They recommended using their analysis for examining the impact of future vertical expansion on solar access to open spaces. In terms of the predicted mean vote, Hegazy and Qurnfulah [49] conducted a detailed investigation of thermal-comfort conditions in four selected urban areas of Jeddah city, Saudi Arabia. They performed a simulation using the ENVI-met software and explored the role of street orientation under summer and winter conditions. Liu et al. [50] investigated the impact of community form and building shading on heating and cooling energy demands. They conducted a parametric simulation using Grasshopper and EnergyPlus, and examined the impact of different building densities in this regard. They considered several building configurations in parallel, as well as staggered rows and several climate zones in China. Based on the results, they proposed a model that quickly estimates the building energy demand under different shading scenarios. However, the impacts of urban density and building configuration as essential factors require further investigation. To advance the current research in this field, the present study investigates the potential impact of urban densification on urban-shading enhancement, considering row-house typology under the urban and climatic conditions of Saudi Arabia.

\section{Materials and Methods}

This study aimed to examine the potential role of housing densification for improving open-space urban shading considering the hot climate of Saudi Arabia. To achieve this aim, our study adopted the following methods (Figure 1) to analyze a case study:

- Analysis of the urban environment: A local row-housing project was analyzed via direct observation. This project was selected as an example of housing densification with a row-house pattern.

- Analysis of urban shading: Based on the urban analysis of the case study, the study carried out a parametric shading analysis using simulation. The study considered row-house attachment method, height, and orientation as independent variables. The amount of outdoor shading was calculated for two parallel rows of housing blocks enclosing a linear courtyard. From the relationships between the examined variables, the urban settings that can maximize shading in the linear courtyard were recommended. 


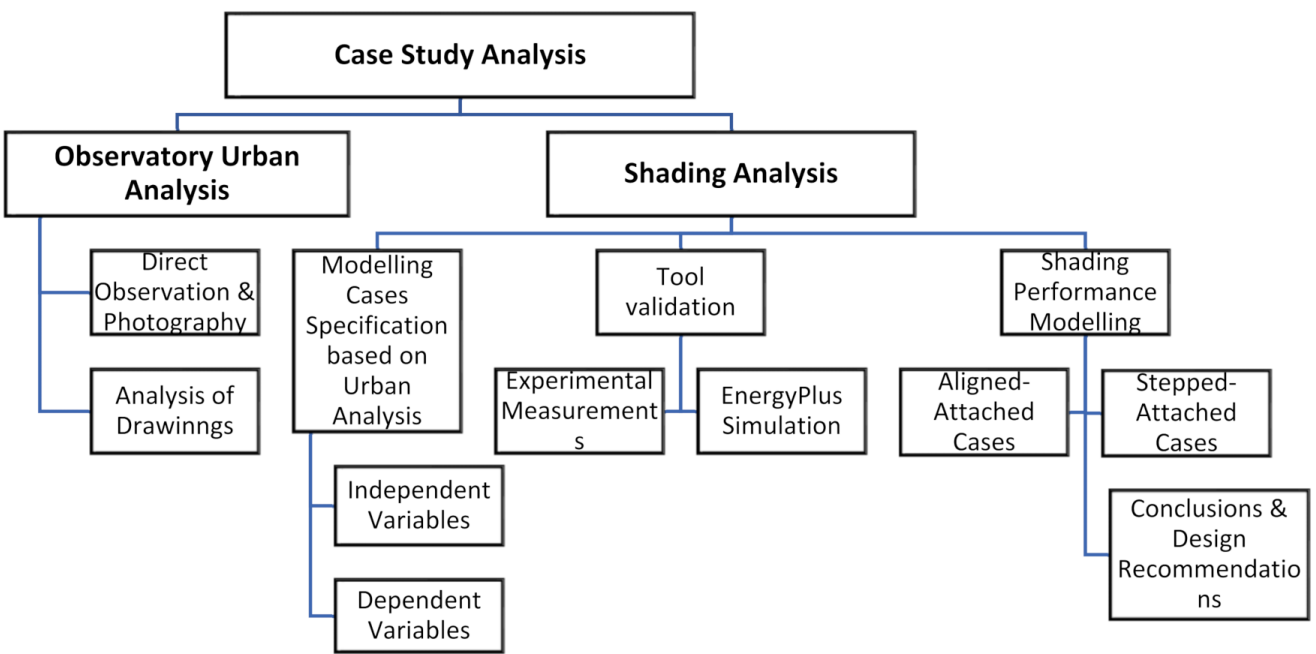

Figure 1. Workflow diagram of the research methods.

The numerical model was constructed using the DesignBuilder v5.5 modeling tool. DesignBuilder is a validated building simulation program that uses EnergyPlus as the simulation engine for conducting energy calculations. Based on the BLAST and DOE-2 models [51], this tool has a user-friendly interface and a variety of outputs that are used to evaluate the environmental performances of buildings, including internal temperature, energy-consumption breakdown, heat-transfer analysis, and thermal-comfort calculators. In the present study, the main DesignBuilder output was the sunlit fraction of the courtyard enclosed by the building rows. This is achieved through analyzing the surface outputs of the examined linear courtyard, where maximizing the shading or minimizing the sunlit fraction is the desired strategy. The workflow of DesignBuilder begins by drawing the examined building three-dimensionally, and specifying its geographic location, the modeling parameters, and the required outputs. Next, it runs the simulation and obtains the results. The following inputs are also considered:

- Block shape: Rectangular $(8 \mathrm{~m} \times 12 \mathrm{~m})$ with the short façade facing the courtyard. Floor area was assumed to be fixed in all cases $\left(8 \mathrm{~m} \times 12 \mathrm{~m}=96 \mathrm{~m}^{2}\right)$.

- $\quad$ Building height: One to four floors with a floor height of $h=3.5 \mathrm{~m}$.

- Linear courtyard width: $4 \mathrm{H}=14 \mathrm{~m}$ (where $H$ is the building height), giving a maximum aspect ratio (AR) of 1.0 (Table 1 ).

- $\quad$ Block shifting distance of the stepped blocks: $4 \mathrm{~m}$ (33\% of the long façade length).

- Building type and occupancy: Residential, 0.04 people $/ \mathrm{m}^{2}$ (four people per floor).

- Metabolic rate: 110 and $130 \mathrm{~W} /$ person for women and men, respectively.

- Clothing: 1.0 and 0.5 clo in winter and summer, respectively.

- Sensible gains (lighting and equipment): $10 \mathrm{~W} / \mathrm{m}^{2}$.

- HVAC system: Full air conditioning powered by electricity (split units). Heating and cooling set-point temperatures: $20^{\circ} \mathrm{C}$ and $24^{\circ} \mathrm{C}$, respectively.

- Window parameters: Window area $=20 \%$ of the façade, shaded with internal blinds. Windows in the attached building configurations (aligned and stepped) are provided on the front and back facades only.

- Material U-values [52]: cavity external wall $=0.34 \mathrm{~W} / \mathrm{m}^{2} . \mathrm{K}$, concrete roofs $=0.2 \mathrm{~W} / \mathrm{m}^{2} . \mathrm{K}$, and double-glazing windows $=2.67 \mathrm{~W} / \mathrm{m}^{2} . \mathrm{K}$.

- Climatic conditions: The latitude range of Saudi Arabia is $31^{\circ} \mathrm{N}-17.5^{\circ} \mathrm{N}$, within the so called sun-belt area $\left(40^{\circ} \mathrm{N}-40^{\circ} \mathrm{S}\right)$ [53]. Its climate has several zones of variability, [54] but the climate generally belongs to the hot desert category, according to the Köppen climate classification system [55]. Thus, the climatic data of Riyadh were considered in this study. 
Table 1. Relationships between building height and courtyard width in the examined cases.

\begin{tabular}{|c|c|c|c|}
\hline No. of Floors $(N)$ & $\begin{array}{l}\text { Building Height } \\
\quad(\mathrm{H}=\mathrm{N} \times 3.5)\end{array}$ & Courtyard Width $(W)$ & Aspect Ratio $=(H / W)$ \\
\hline 1 & $3.5 \mathrm{~m}$ & $4 \times 3.5=14 \mathrm{~m}$ & 0.25 \\
\hline 2 & $7.0 \mathrm{~m}$ & $4 \times 3.5=14 \mathrm{~m}$ & 0.5 \\
\hline 3 & $10.5 \mathrm{~m}$ & $4 \times 3.5=14 \mathrm{~m}$ & 0.75 \\
\hline 4 & $14.0 \mathrm{~m}$ & $4 \times 3.5=14 \mathrm{~m}$ & 1.0 \\
\hline
\end{tabular}

\section{Results and Discussion}

\subsection{Observatory Analysis of the Urban Environment}

This subsection overviews the Al-Ferdaws housing project located within the campus of King Fahd University of Petroleum and Minerals (KFUPM) in Dhahran, Saudi Arabia. This project was selected as a relatively compact housing planning and design that is uncommon in the Saudi housing environment, as discussed in the literature review. The project was planned to accommodate staff members of the KFUPM faculty and their families on an approximate area of $\sim 14$ ha. Along with other interesting elements of landscaping and green areas, the project includes housing blocks, access roads and car parks, pedestrian walkway networks, semipublic open spaces (linear courtyards), and services (mosques and public-events halls). It includes 454 attached or semiattached housing units linearly arranged in two orientations: north-south (N-S) and east-west (E-W). The general density of the project is $\sim 33$ housing units per hectare, which is considered reasonable in the context of housing densification in Saudi Arabia under international and local recommendations [11,56].

To ensure high accessibility to houses, several blocks of row houses are arranged parallel to each other and to the local roads (cul-de-sacs), where the house entrances are easily approached via several linear courtyards bounded by these blocks. Moreover, this layout improves the efficiency of land subdivision and is appropriate for treating the irregular nature of the site, especially in the southern zone (Figure 2). The project plan discourages thorough traffic by constructing a ring road and a set of cul-de-sacs terminated by roundabouts. Local roads in the project represent only $~ 13 \%$ of the project area, thereby increasing the share of other land uses and creating an effective road hierarchy that reduces the speed and scale of roads to favor residential land use. Car parks of various forms are well-distributed throughout the project. They include car-park courts and on-street car parks at a reasonable distance from the doors of the housing units. This fragmented car-park pattern and the screening of cars in sheds were designed to reduce the negative visual impact of vehicles.

Pedestrian movement is separated from car movement along a separated network of shaded paths that effectively connect the different courtyards. The pedestrian paths enhance the continuity of courtyards and create a network of open spaces by which pedestrians can easily move between courtyards and cul-de-sacs. Entry points to the courtyards are well-defined, with wooden sheds to separate the semipublic and public spaces. Open spaces are provided by shared courtyards bounded by the row houses in a linear pattern. The courtyards are mainly shaded by building masses (Figure 3). Each courtyard contains a central play area for children, which is shaded by membrane structures. Sharing of the courtyards reduces the impact of stacking the housing units, and enhances the sense of openness. Meanwhile, to enhance the sense of privacy, the central courtyard is divided into a series of zones using several territorial measures, such as narrowing of the areas between spaces, change of level, and change of direction. These measures further improve the visual quality of the project by creating a serial visual effect and a continuous change from sun to shade during movement through the central courtyard (Figure 3). This change visually engages the users in their urban environment. This shows that row houses don't essentially have to be hyper-repetitive building forms to achieve their design goals. A form with more irregularity is recommended to improve users' experience. However, the uniqueness of 
each courtyard should be increased to enhance the visual contrast in landscape elements, building materials, colors, and other features.

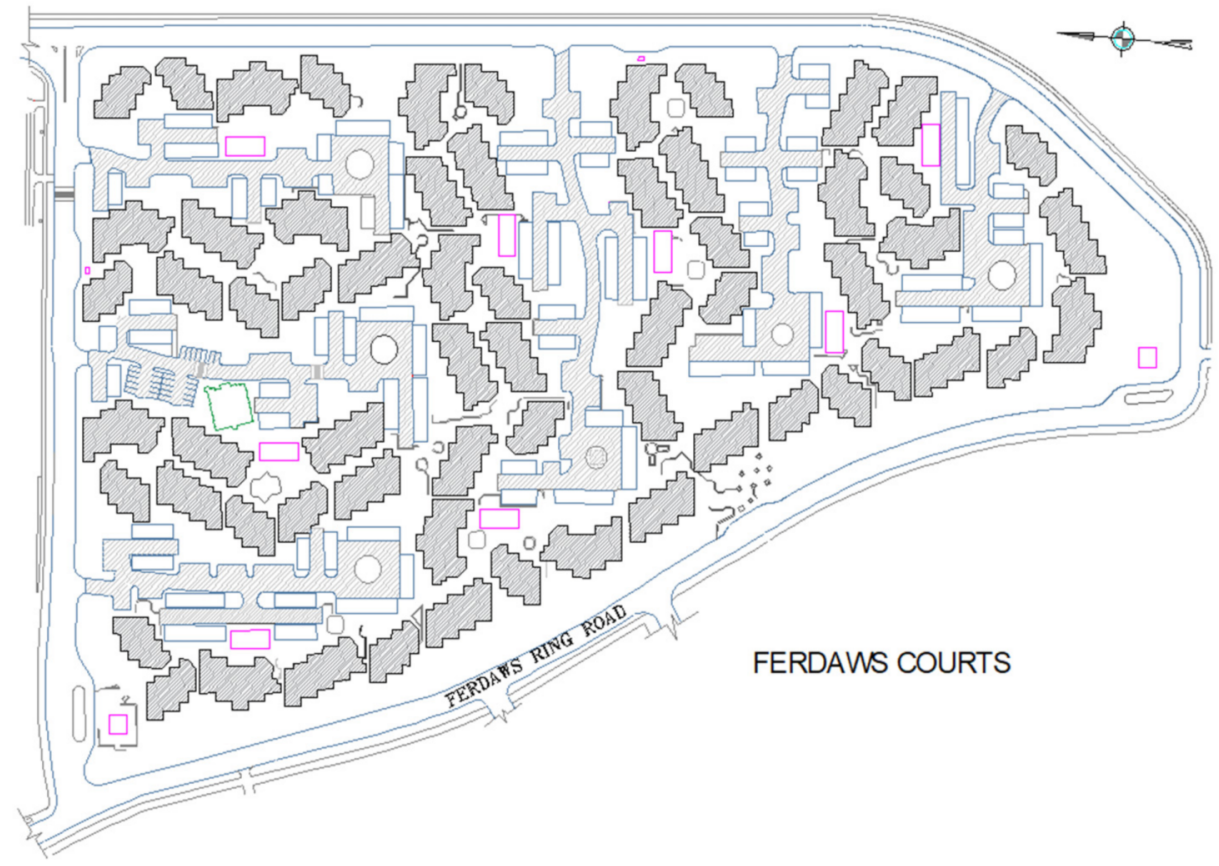

Figure 2. Plan of the Al-Ferdaws housing project site, Dhahran, Saudi Arabia ([57]; reproduced by the author).
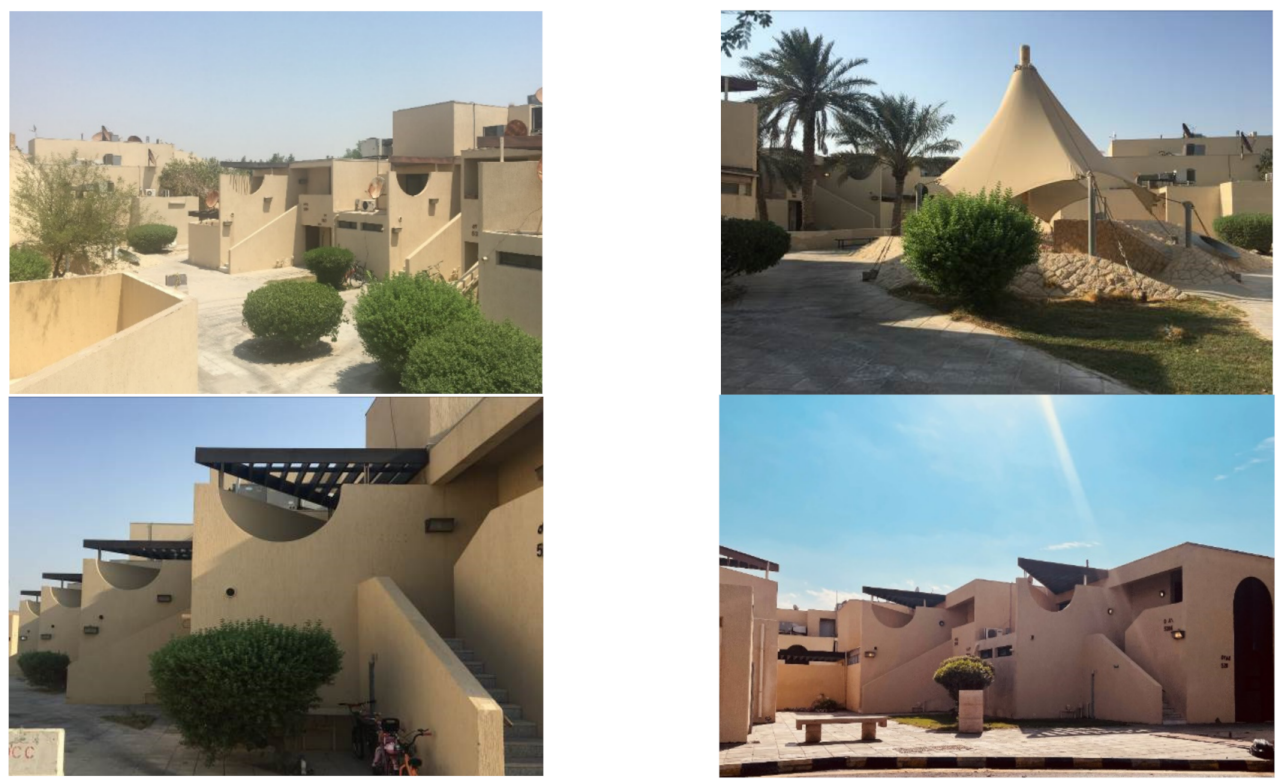

Figure 3. A typical courtyard (top) and housing units (bottom) in the Al-Ferdaws housing project, Dhahran, Saudi Arabia.

For the design of housing units, the project includes several types of units to fit several family sizes. The most common strategy in this regard is using a three-story block design, where the ground floor comprises a two-bedroom unit and the top floors comprise threebedroom duplex units. The areas of these two types of units are approximately 130 and $220 \mathrm{~m}^{2}$, respectively. The units are generally well-designed with conscious distribution of the allocated space. However, they do not provide separate sitting rooms for male and 
female visitors, thus ignoring common practice followed in Saudi Arabia. In general, the design pays considerable attention to the shading issue on both the urban and architectural design levels. This attention is noticeable in the housing-unit design, where the extensive use of balconies bounded by raised parapet walls improves their shading potential, and in the use of building masses as shading elements of the enclosed courtyards. This shading potential is numerically investigated in the following section of the study.

\subsection{Analysis of Urban Shading}

Prior to the planned shading analysis, the selected simulation code must be verified using experimental measurements. To do so, the housing blocks and enclosed courtyards were represented using scaled physical models. These physical models were exposed to the sun in Dhahran city for approximately two weeks during the autumn season (from 25 October to 12 November 2021). The resulting shading in the courtyard was recorded using digital photography (two readings per day). The percentage of shaded area in the courtyard was then calculated using the AutoCAD program. The resulting experimental hourly data were compared with DesignBuilder data using similar settings. Initially, the hourly data of the sunlit fraction obtained from the DesignBuilder simulation tab were applied over the entire open-space surface area. However, these data showed a high discrepancy ( $20 \%$ ) from the measured data. After contacting the software developer, the author learned that DesignBuilder divides any complex surface into several simple square and/or rectangular subsurfaces before calculating the sunlit fraction. In the examined case shown in Figure 4, the open-space external surface was divided into five subsurfaces with different areas. Using the Results Viewer tool, the hourly sunlit fraction values were determined over each subsurface. The value obtained was then multiplied by the subsurface area to obtain the area-weighted average sunlit fraction, which was then divided by the total open-space area to determine the average sunlit fraction Equation (1):

$$
S w=\frac{\sum_{i=1}^{n} S i \times A i}{\sum_{i=1}^{n} A i}
$$

where $S w$ is the total weighted sunlit fraction in a given hour, $S i$ is the sub-surface hourly sunlit fraction, $A i$ is sub-surface area, and $n$ is number of sub-surfaces. This process resulted in more accurate hourly data of sunlit fraction. This process was only necessary for the sunlit fraction hourly data. As for daily averages, there was no significant difference between the sunlit fraction daily average obtained directly from the DesignBuilder simulation tab and from Results Viewer tool.
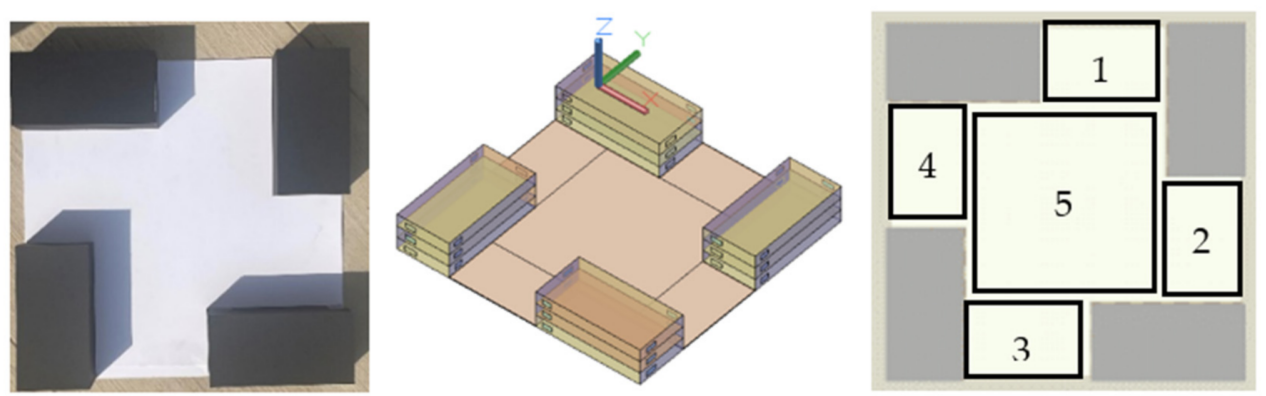

Figure 4. Physical models used in shading measurements, and the method of dividing the open-space external surface into five subsurfaces using DesignBuilder.

The measured and modeled data were again compared, and the results are shown in Figure 5. The average discrepancy was 7.8\%, indicating a good agreement between the two methods and the validation of the implemented simulation code. After verifying the proposed modeling process, it is possible to proceed with the modeling part of this study. This part aims to investigate the shading potential of row houses in the demonstrated case study. The row houses are three stories high and planned in a linear pattern. The ground 
floor comprises a one-floor unit and the top two floors comprise duplex units. To increase the applicability of the results, this typology was simplified and modeled considering the following as independent variables (Figure 6):

- Building configuration: Aligned-attached (Aa) and stepped-attached (As) houses. By changing the building configuration, we can investigate how the aligned- and stepped-attachment methods affect the outdoor shading.

- Housing density by increasing the number of floors $(1,2,3$, and 4 , corresponding to the ARs of $0.25,0.50,0.75$, and 1.0 , respectively).

- Linear courtyard orientation: N-S and E-W.

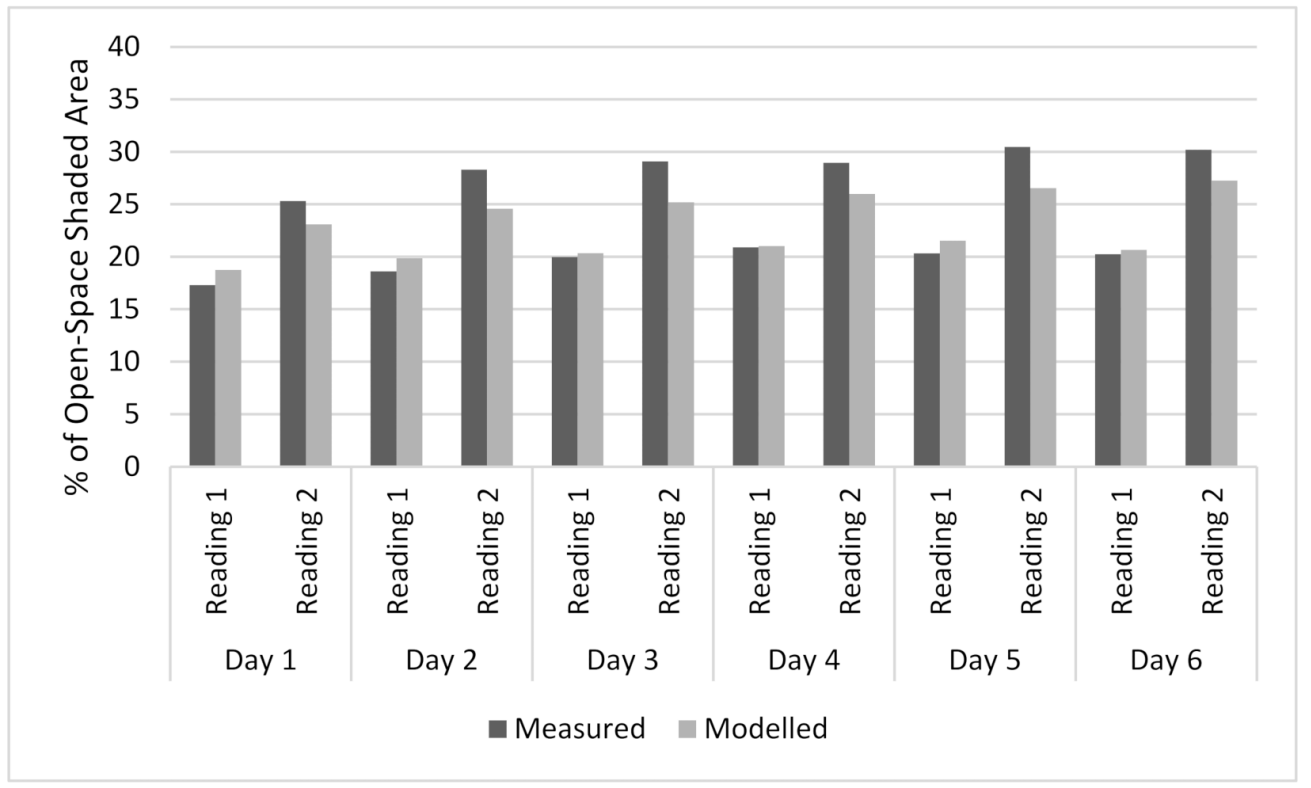

Figure 5. Comparison between experimental and modeled shading data.

The percentage of courtyard shaded area was considered as the main dependent variable. Figure 6 shows the modeling cases and their corresponding codes. The first, second, and third code assignments indicate the number of floors, courtyard orientation, and building configuration, respectively, in each case. Sixteen cases were examined herein (Figure 6). Figure 7 shows the shading analysis results. In general, the shading potential in the courtyard was higher in winter than in summer; however, the design will prioritize high shading potential under the prevailing summer conditions. Results show that the shaded area in the courtyard increased with increasing AR of the courtyard, i.e., with increasing building height. For example, when the building height was four floors, the percentages of courtyard shaded in the E-W courtyard orientation were $21.6 \%$ and $33.8 \%$ for the Aa and As configurations, respectively. That is, the As configuration improved the shade percentage by $56.5 \%$. In the As building configuration, the housing blocks are attached with a shifting distance of $4 \mathrm{~m}$ ( $33 \%$ of the long façade), meaning that one third of the façade length faces the east and west directions. This alignment increases the building exposure to the morning and afternoon sun from that of the Aa configuration, thus offering a higher shading potential in the courtyard. 


\begin{tabular}{|c|c|c|c|c|}
\hline & \multicolumn{2}{|c|}{$\begin{array}{c}\text { Aligned Attached } \\
\text { (Aa) }\end{array}$} & \multicolumn{2}{|c|}{$\begin{array}{l}\text { Stepped Attached } \\
\text { (As) }\end{array}$} \\
\hline & E-W & N-S & E-W & $\mathrm{N}-\mathrm{S}$ \\
\hline \multirow[t]{2}{*}{$\begin{array}{c}1 \text { Floor } \\
(\mathrm{AR}= \\
0.25)\end{array}$} & & & & \\
\hline & 1-EW-Aa & 1-NS-Aa & 1-EW-As & 1-NS-As \\
\hline \multirow[t]{2}{*}{$\begin{array}{c}2 \text { Floors } \\
(\mathrm{AR}= \\
0.50)\end{array}$} & & & & \\
\hline & 2-EW-Aa & 2-NS-Aa & 2-EW-As & 2-NS-As \\
\hline \multirow[t]{2}{*}{$\begin{array}{c}3 \text { Floors } \\
(\mathrm{AR}= \\
0.75)\end{array}$} & & & & \\
\hline & 3-EW-Aa & 3-NS-Aa & 3-EW-As & 3-NS-As \\
\hline \multirow[t]{2}{*}{$\begin{array}{c}4 \text { Floors } \\
(\mathrm{AR}=1.0)\end{array}$} & $\Rightarrow$ & & & \\
\hline & 4-EW-Aa & 4-NS-Aa & 4-EW-As & 4-NS-As \\
\hline
\end{tabular}

Figure 6. Illustrations and codes of the modeling cases.

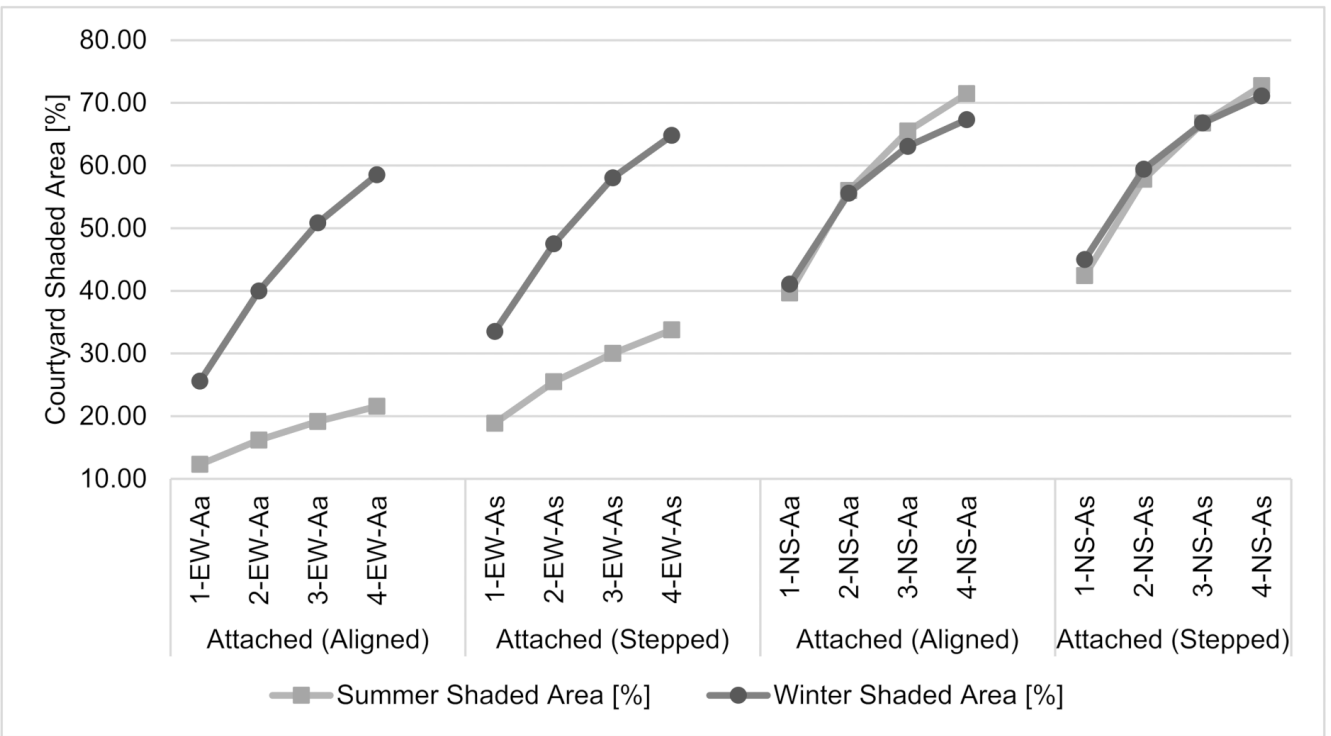

Figure 7. Percentages of courtyard shaded areas in summer and winter observed in different modeling cases with E-W and N-S courtyard orientations. 
For the four-story buildings in the N-S courtyard orientation, the percentages of courtyard shaded area in summer were $71.5 \%$ and $72.7 \%$ for the Aa and As configurations, respectively. An insignificant difference between the two configurations was observed in this orientation. However, this orientation generally offers a higher shading potential than that of the E-W orientation, because the long eastern and western facades of the buildings in the N-S orientation are exposed to the low morning and evening sun, which significantly increases the amount of shading in the open space (Figure 8). Thus, it was concluded that the $\mathrm{N}-\mathrm{S}$ orientation of the courtyard offers more summer shading than the E-W orientation in both the stepped and aligned attachment methods. However, the stepped attachment method improves the shading potential in the E-W orientation, the usually recommended orientation in hot climates.

\begin{tabular}{|c|c|c|c|c|}
\hline Case & 2-EW-Aa & 2-EW-As & 2-NS-Aa & 2-NS-As \\
\hline $\begin{array}{c}\text { Cooling Energy } \\
{\left[\mathrm{kWh} / \mathrm{m}^{2}\right]}\end{array}$ & 6.6 & 6.8 & 7.3 \\
\hline $\begin{array}{c}\text { Shading } \\
\text { illustration } \\
\text { (north is up) }\end{array}$ & & & & \\
\hline
\end{tabular}

Figure 8. Stepped and aligned shading patterns in the courtyard, observed at 4:00 pm on 1 August 1.

Furthermore, the impacts of the examined configurations on the thermal performance of the buildings are important. Figure 8 shows the impact of the attachment method (Aa or As) on the normalized cooling energy in summer. With smaller surface area than the As buildings, the Aa buildings required lower cooling energy in both the E-W and N-S orientations. Meanwhile, the E-W orientation required less cooling energy because the long building facades were not directly exposed to the east and west sunrays. However, case 2-EW-As required slightly higher cooling energy than case 2-EW-Aa, because (owing to its stepped pattern) case 2-EW-As was partially exposed to the east and west sunrays. This increase may be mitigated by the higher shading potential of stepped buildings than that of the aligned ones, as demonstrated in the previous subsection.

\section{Conclusions}

As an oil-producing country, Saudi Arabia relies mainly on fossil fuel to meet its increasing energy demand. Domestic energy consumption is a main category of fuel use. Therefore, sustainable housing strategies and energy-efficient practices, such as housing densification, are urgently required. For this, sufficient and adequate open spaces embedded in the residential environment are also important. This is crucial to improve urban shading and attract people to using these outdoor open spaces, especially under hot climatic conditions. Thus, using a real-time case study, the present study aimed to investigate the impact of housing densification on the performance of open-space shading. Within the investigated housing project, rows of houses enclosed linear courtyards. The empirical investigation was followed by a numerical investigation of the resulting urban shading to determine the impacts of attaching housing units horizontally and stacking them vertically. This was conducted considering the variables, such as building height, courtyard orientation, and the attachment method of the housing blocks (aligned or stepped). This comparative parametric study has practical value, because it considers the different interacting variables under different testing scenarios.

It was concluded that row houses could offer an acceptable solution to housing densification in Saudi Arabia. They could be compactly arranged with well-integrated open spaces that improved the quality of the residential environment. The shading of these open spaces was significantly affected by the housing density, grouping pattern, and 
orientation of the row houses. Selecting an appropriate building-attachment method was important for improving courtyard shading. In the E-W orientation, the As housing pattern improved the urban-shading potential by $\sim 56 \%$ from that of the Aa pattern because the As pattern increases the chance of building's exposure to the sun from different directions, thus improving shading in the courtyard. In addition, the As housing pattern effectively improved visual quality and created a serial visual effect in the examined case study.

The findings of this study confirm that it is essential in the context of housing urban design to guide the rapid housing growth in hot climates towards effective shading growth. This study recommends a further investigation of the impact of other passive urbandesign strategies to improve the thermal comfort conditions in residential open spaces. Such investigations should involve determining the effects of vegetation, albedo, and paving materials on open spaces. This study recommends that the use of compact housing patterns in Saudi Arabia should be promoted to reduce the rapidly increasing domestic electrical-energy demand and improve the degree of urban shading. Housing densification is believed to be an effective passive design and planning strategy for this purpose, in addition to other common strategies, such as building massing, orientation, shading, insulation, and vegetation.

Funding: The Article Processing Charges (APCs) was funded by King Fahd University of Petroleum \& Minerals (KFUPM).

Institutional Review Board Statement: Not applicable.

Informed Consent Statement: Not applicable.

Data Availability Statement: The data presented in this study are available on request from the corresponding author.

Acknowledgments: The author would like to acknowledge King Fahd University of Petroleum \& Minerals (KFUPM) for their financial support.

Conflicts of Interest: The author declares no conflict of interest.

\section{References}

1. Edwards, B.; Hyett, P. Rough Guide to Sustainability; RIBA: London, UK, 2002.

2. Ouda, O.K.M.; Nakla, S.; Yahya, C.; Peterson, H.; Ouda, M. Energy conservation awareness among residential consumers in Saudi Arabia. Int. J. Comput. Digit. Syst. 2017, 6, 349-355.

3. Aldossary, N.A.; Rezgui, Y.; Kwan, A. An investigation into factors influencing domestic energy consumption in an energy subsidized developing economy. Habit. Int. 2015, 47, 41-51. [CrossRef]

4. SEEC. Saudi Energy Efficiency Center Energy Sectors: Buildings. Available online: https://www.seec.gov.sa/en/energy-sectors/ buildings-sector/ (accessed on 23 March 2021).

5. Hamdan, D.M.A.; de Oliveira, F.L. The impact of urban design elements on microclimate in hot arid climatic conditions: Al Ain City, UAE. Energy Build. 2019, 200, 86-103. [CrossRef]

6. Hsieh, C.; Li, J.; Zhang, L.; Schwegler, B. Effects of tree shading and transpiration on building cooling energy use. Energy Build. 2018, 159, 382-397. [CrossRef]

7. Broitman, D.; Koomen, E. Residential density change: Densification and urban expansion. Comput. Environ. Urban Syst. 2015, 54, 32-46. [CrossRef]

8. Skovbro, A. Urban densification-A sustainable urban policy? In The Sustainable City II; Brebbia, C.A., Martin-Duque, J.F., Wadhwa, L.C., Eds.; WIT Press: Southampton, UK, 2002; pp. 517-527.

9. Touati-Morel, A. Hard and soft densification policies in the Paris city-region. Int. J. Urban Region. Res. 2015, 39, 603-612. [CrossRef]

10. Jaksch, S.; Franke, A.; Österreicher, D.; Treberspurg, M. A systematic approach to sustainable urban densification using prefabricated timber-based attic extension modules. Energy Proc. 2016, 96, 638-649. [CrossRef]

11. Asfour, O.S. Towards an effective strategy to cope with housing land scarcity in the Gaza Strip as a sustainable development priority. Habit. Int. 2012, 36, 295-303. [CrossRef]

12. Vuckovic, M.; Loibl, W.; Tötzer, T.; Stollnberger, R. Potential of urban densification to mitigate the effects of heat island in Vienna, Austria. Environments 2019, 6, 82. [CrossRef]

13. Xue, F.; Gou, Z.; Lau, S.S.Y. Green open space in high-dense Asian cities: Site configurations, microclimates and users' perceptions. Sustain. Cities Soc. 2017, 34, 114-125. [CrossRef] 
14. Francis, J.; Wood, L.J.; Knuiman, M.; Giles-Corti, B. Quality or quantity? Exploring the relationship between public open space attributes and mental health in Perth, Western Australia. Soc. Sci. Med. 2012, 74, 1570-1577. [CrossRef] [PubMed]

15. Al Obaid, H.M.A. Factors determining housing demand in Saudi Arabia. Int. J. Econom. Finan. Issues 2020, 10, 150-157. [CrossRef]

16. Haidar, E.A.; BaHammam, A.S. An optimal model for housing projects according to the relative importance of affordability and sustainability criteria and their implementation impact on initial cost. Sustain. Cities Soc. 2021, 64, 102535. [CrossRef]

17. Vision 2030. Vision 2030 Kingdom of Saudi Arabia. Available online: https:/ /vision2030.gov.sa/en (accessed on 4 October 2021).

18. Sakani about Sakani. Available online: https://sakani.housing.sa/en_sakani (accessed on 12 December 2021).

19. Alhamoudi, A.; Lee, P. Chapter 24 Smart growth and real estate development in Saudi Arabia. In Routledge Handbook of Sustainable Real Estate; Wilkinson, S., Dixon, T., Miller, N., Sayce, S., Eds.; Routledge: London, UK, 2018.

20. Aljoufie, M.; Tiwari, A. Exploring housing and transportation affordability in Jeddah. Hous. Pol. Debate 2020, 1-27. [CrossRef]

21. General Authority of Statistics Housing Statistics. Available online: https://www.stats.gov.sa/en/911-0 (accessed on 12 December 2021).

22. Alhazmi, A.; Elhag, A.; Thabit, H. Economic housing to meet the requirements of the young newlywed marriage study on Qassim, Saudi Arabia (2030 Vision). Mansoura Eng. J. 2018, 43, A-1-A-11. [CrossRef]

23. Shirvani, H. The Urban Design Process; Nostrand-Reinhold: New York, NY, USA, 1985.

24. Carmona, M. Principles for public space design, planning to do better. Urban Des. Int. 2019, 24, 47-59. [CrossRef]

25. Azad, S.P.; Morinaga, R.; Kobayashi, H. Effect of Housing Layout and Open Space Morphology on Residential EnvironmentsApplying New Density Indices for Evaluation of Residential Areas Case Study: Tehran, Iran. J. Asian Architect. Build. Eng. 2018, 17, 79-86. [CrossRef]

26. United States Environmental Protection Agency (EPA). What Is Open Space/Green Space? Available online: https://www3.epa. gov/region1/eco/uep/openspace.html (accessed on 1 November 2021).

27. UN-Habitat City-Wide Public Space Strategies: A Guidebook for City Leaders; United Nations Human Settlement Programme (UN-Habitat): Nairobi, Kenya, 2020.

28. World Health Organization (WHO). Urban Green Spaces: A Brief for Action. 2017. Available online: https://www.euro.who.int/ _data/assets/pdf_file/0010/342289/Urban-Green-Spaces_EN_WHO_web3.pdf (accessed on 1 November 2021).

29. UN-Habitat. SDG Indicator 11.7.1 Training Module: Public Space; United Nations Human Settlement Programme (UN-Habitat): Nairobi, Kenya, 2018.

30. Saudi Vision 2030. Quality of Life Program 2020 Delivery Plan. Available online: https://planipolis.iiep.unesco.org/sites/ default/files/ressources/saudi_arabia_quality_of_life.pdf (accessed on 1 November 2021).

31. Bakarman, M.A.; Chang, J.D. The influence of height/width ratio on urban heat island in hot-arid climates. Proc. Eng. 2015, 118, 101-108. [CrossRef]

32. Yue, W.; Liu, X.; Zhou, Y.; Liu, Y. Impacts of urban configuration on urban heat island: An empirical study in China mega-cities. Sci. Total Environ. 2019, 671, 1036-1046. [CrossRef]

33. Liang, H.; Meng, Q.; Qi, Q.; Ren, P. Spatiotemporal interaction between urban heat island and urban-construction indicators on the block scale in autumn in a humid and hot climate. Sustain. Cities Soc. 2022, 78, 103638. [CrossRef]

34. Almutairi, M.K. Derivation of urban heat island for Landsat-8 TIRS Riyadh city (KSA). J. Geosci. Environ. Protect. 2015, 3, 18-23. [CrossRef]

35. Jato-Espino, D. Spatiotemporal statistical analysis of the urban heat island effect in a Mediterranean region. Sustain. Cities Soc. 2019, 46, 101427. [CrossRef]

36. Cheela, V.R.S.; John, M.; Biswas, W.; Sarker, P. Combating urban heat island effect-A review of reflective pavements and tree shading strategies. Buildings 2021, 11, 93. [CrossRef]

37. WeatherOnline. Available online: https://www.weatheronline.co.uk/reports/climate/Saudi-Arabia.htm (accessed on 23 August 2020).

38. Al-Masri, N.; Abu-Hijleh, B. Courtyard housing in midrise buildings: An environmental assessment in hot-arid climate. Renew. Sustain. Energy Rev. 2012, 16, 1892-1898. [CrossRef]

39. Al-Hafith, O.; Satish, B.K.; Bradbury, S.; de Wilde, P. The impact of courtyard parameters on its shading level an experimental study in Baghdad, Iraq. Energy Proc. 2017, 134, 99-109. [CrossRef]

40. Al-Hafith, O.; Satish, B.K.; Bradbury, S.; de Wilde, P. The impact of courtyard compact urban fabric on its shading: Case study of Mosul city, Iraq. Energy Proc. 2017, 122, 889-894. [CrossRef]

41. Sharifi, A. Urban form resilience: A meso-scale analysis. Cities 2019, 93, 238-252. [CrossRef]

42. Soflaei, F.; Shokouhian, M.; Abraveshdar, H.; Alipour, A. The impact of courtyard design variants on shading performance in hotarid climates of Iran. Energy Build. 2017, 143, 71-83. [CrossRef]

43. Lima, I.; Scalco, V.; Lamberts, R. Estimating the impact of urban densification on high-rise office building cooling loads in a hot and humid climate. Energy Build. 2019, 182, 30-44. [CrossRef]

44. Wai, K.M.; Yuan, C.; Lai, A.; Yu, P.K.N. Relationship between pedestrian-level outdoor thermal comfort and building morphology in a high-density city. Sci. Total Environ. 2020, 708, 134516. [CrossRef]

45. Abdallah, A.S.H.; Hussein, S.W.; Nayel, M. The impact of outdoor shading strategies on student thermal comfort in open spaces between education building. Sustain. Cities Soc. 2020, 58, 102124. [CrossRef] 
46. Chan, L.S. Investigating the thermal performance and overall thermal transfer value (OTTV) of air-conditioned buildings under the effect of adjacent shading against solar radiation. J. Build. Eng. 2021, 44, 103211. [CrossRef]

47. Masoud, B.; Coch, H.; Crespo, I.; Beckers, B. Effects of urban morphology on shading for pedestrians. In Proceedings of the PLEA 2018, Hong Kong, China, 10-12 December 2018.

48. Moro, J.; Krüger, E.L.; Camboim, S. Shading analysis of urban squares using open-source software and free satellite imagery. Appl. Geom. 2020, 12, 441-454. [CrossRef]

49. Hegazy, I.R.; Qurnfulah, E.M. Thermal comfort of urban spaces using simulation tools exploring street orientation influence of on the outdoor thermal comfort: A case study of Jeddah, Saudi Arabia. Int. J. Low Carbon Technol. 2020, 15, 594-606. [CrossRef]

50. Liu, H.; Pan, Y.; Yang, Y.; Huang, Z. Evaluating the impact of shading from surrounding buildings on heating/ cooling energy demands of different community forms. Build. Environ. 2021, 206, 108322. [CrossRef]

51. Shabunko, V.; Lim, C.M.; Mathew, S. EnergyPlus models for the benchmarking of residential buildings in Brunei Darussalam. Energy Build. 2018, 169, 507-516. [CrossRef]

52. Saudi Standards, Metrology and Quality Organization (SASO). Thermal Transmittance Values for Residential Buildings. 2014. Available online: https:/ / www.momra.gov.sa/GeneralServ/heatiso/Insulation\%20Regulation\%20Summary\%20(English)_v2 .pdf (accessed on 23 March 2021).

53. Almasoud, A.H.; Gandayh, H.M. Future of solar energy in Saudi Arabia. J. King Saud Univ. Eng. Sci. 2015, 27, 153-157. [CrossRef]

54. Alrashed, F.; Asif, M. Analysis of critical climate related factors for the application of zero-energy homes in Saudi Arabia. Renew. Sustain. Energy Rev. 2015, 41, 1395-1403. [CrossRef]

55. Wikipedia. Köppen Climate Classification. Available online: https://en.wikipedia.org/wiki/K\%C3\%B6ppen_climate_ classification (accessed on 23 March 2021).

56. Royal Commission for Riyadh City (RCRC). Housing Density: An Effective Tool for Managing City Growth. Available online: https:/ / www.rcrc.gov.sa/ar/magazine_topic/005914 (accessed on 4 October 2021).

57. King Fahd University of Petroleum and Minerals (KFUPM). KFUPM Map. Available online: http://www.kfupm.edu.sa/ committee/tsc/SiteAssets/Lists/ContentPages_Arabic/EditContentPage/KFUPM\%20MAP.pdf (accessed on 23 March 2021). 